\title{
Analysis of State and Federal Regulatory Regimes Potentially Governing the Extraction of Water from Carbon Storage Reservoirs in the United States
}

\author{
Jenna N. Schroeder, Christopher B. Harto, and Corrie E. Clark ${ }^{\text {ab }}$
}

\begin{abstract}
Extracted water - water brought to the surface of the ground during carbon capture and sequestration (CCS) projects to create additional room for carbon dioxide injectionexists in a murky legal environment. As part of a broader attempt to identify the complex interactions between water resource policies and CCS, an analysis was undertaken at both the state and the federal level to scope the policy environments surrounding extracted water policies and laws. Six states (California, Illinois, Mississippi, Montana, North Dakota, and Texas) were chosen for this analysis because either active CCS work is currently underway, or the potential exists for future work. Although regulation of extracted waters could potentially occur at many points along the CCS life cycle, this paper focuses on regulation that may apply when the water is withdrawn - that is, accessed and removed from the saline aquifer - and when it is re-injected in a close but unconnected aquifer. It was found that no regulations exist for this source specifically. In addition, greater input is needed from regulators and policy makers in terms of defining this resource. In particular, regulation of extracted waters (and CCS activities broadly) often overlaps with the management of fluids produced during oil and gas development. Many regulations would apply to extracted waters if they were classified as such. Therefore, correct categorization is key as the industry in this space continues to grow.
\end{abstract}

Keywords: carbon capture and storage; CCS; energy water nexus; extracted water; policy; management 


\section{INTRODUCTION}

Recently, a great deal of discussion has centered on the geological sequestration of carbon dioxide $\left(\mathrm{CO}_{2}\right)$. For sequestration to have a reasonably positive impact on atmospheric carbon levels, the anticipated volume of $\mathrm{CO}_{2}$ that would need to be injected is very large (many millions of tons per year). Many stakeholders have expressed concern about elevated formation pressure following the extended injection of $\mathrm{CO}_{2}$ (Harto and Veil 2011). The injected $\mathrm{CO}_{2}$ plume could potentially extend many kilometers from the injection well. If not properly managed and monitored, the increased formation pressure could stimulate new fractures or enlarge existing natural cracks or faults, so the $\mathrm{CO}_{2}$ or the brine pushed ahead of the plume could migrate vertically (Harto and Veil 2011).

One possible tool for managing formation pressure is to extract water already residing in the formation where $\mathrm{CO}_{2}$ is being stored. The idea is that by removing water from the receiving formations (referred to here as "extracted water" to distinguish it from oil- and gas-related "produced water"), the pressure gradients caused by injection might be reduced, which could thereby free up additional pore space to sequester $\mathrm{CO}_{2}$ (Harto and Veil 2011). Although water extraction is likely not a mandatory component of large-scale carbon storage programs, it could provide many benefits, such as reduced pressure, increased space for $\mathrm{CO}_{2}$ storage, and potentially better plume management (Harto and Veil 2011).

\section{METHODS}

The goal of this analysis is to identify laws, policies, and regulations that may apply in the case of withdrawing extracted water during carbon capture and storage (CCS) projects. In attempting to identify states for this analysis, we consulted the NATCARB. NATCARB is a geographic information system (GIS)-based tool developed to provide a view of CCS-related variables. This online tool (www.natcarb.org), created and hosted by NETL, allows the user to utilize a variety of analytical tools related to CCS deployment. We used it to identify areas with potential for the kinds of saline reservoirs where extracted water projects would likely be most successful. The search parameters consisted of finding states with terrestrial sequestration potential, but also, importantly, with a moderately low TDS level for extracted waters; treatment of higher-TDS waters is more expensive and, therefore, less likely to proceed from an economic perspective.

Six states were selected using this process. Montana was chosen because it lies within the PCOR (Plains $\mathrm{CO}_{2}$ Reduction Partnership) region, an important basin of deep saline aquifers with low TDS, which also has large quantities of land available for surface treatment of extracted water. Texas was chosen because it is already host to many enhanced oil recovery (EOR) projects, which can be used in conjunction with CCS 
activities in $\mathrm{CO}_{2}$-EOR projects. These projects, which inject $\mathrm{CO}_{2}$ underground to aid in the recovery of oil, are already in use throughout the United States. The Kemper Project, in Mississippi, is one of seven U.S. Department of Energy (DOE)/NETL CCS projects nationwide; when online, it will also be an EOR facility. The importance of the Kemper plant in terms of proving this technology, as well as the high visibility of the project, was the reason Mississippi was also in the analysis. California was chosen as it is an important state from the perspective of being at the forefront of environmental laws and regulations, as well as the large available storage capacity present in the state. Illinois, which is part of the Midwest Region Carbon Sequestration Partnership (MRCSP), was chosen because it is the site of another important DOE demonstration project with Archer Daniels Midland, the Decatur Project. Initial well drilling on this project began in November 2014 and is currently ongoing. Finally, North Dakota was included because it is the only state to apply for primacy for Class VI wells from the U.S. Environmental Protection Agency (EPA) Underground Injection Control (UIC) Program. Class VI wells are the newest class of wells and are specifically used for CCS projects. As such, the state is at the forefront of policy in this field.

Although the main focus of this study is evaluating the regulatory regimes that manage water that would be extracted from formations receiving $\mathrm{CO}_{2}$, it is first helpful to have a preliminary understanding of the quality of the water that would be managed. Harto and Veil (2011) collected data on the chemical composition of saline groundwater obtained from the Kansas Geological Survey, which maintains a large data set in partnership with the National Energy Technology Laboratory (NETL) for the National Carbon Sequestration Database and Geographic Information System (NATCARB) database. The raw data set contains more than 125,000 data records, including much of the data from the U.S. Geological Survey (USGS)-produced water database (http://energy.cr.usgs.gov/prov/prodwat/data2.htm). This data set was cross-referenced with saline formations to evaluate the brines that would likely be encountered during carbon sequestration. This resulted in a smaller data set containing about 41,000 samples. Samples taken at depths shallower than 2,500 feet were not included in this trimmed data set, except where no other data points were available for a specific formation. The 2,500foot depth limit was selected to eliminate data points at depths that do not meet the pressure requirements for successful carbon sequestration (Kobos et al. 2009). The trimmed data set was reviewed and analyzed to help understand the typical conditions that may be encountered in deep saline formations used for carbon sequestration. Brine characteristics include $\mathrm{pH}$ and total dissolved solids (TDS). Data are summarized in Table 1. 
TABLE 1 - Summary of TDS and pH Values for Formation Waters

\begin{tabular}{|l|c|c|c|}
\hline \multicolumn{1}{|c|}{ State } & $\begin{array}{c}\text { Average TDS } \\
(\mathbf{p p m})\end{array}$ & $\begin{array}{c}\text { Median TDS } \\
(\mathbf{p p m})\end{array}$ & Average $\mathbf{~ p H ~}$ \\
\hline & & & \\
\hline California & 25,786 & 29,127 & 6.85 \\
\hline Illinois & 112,688 & 124,256 & 6.73 \\
\hline Mississippi & 153,822 & 157,025 & 6.05 \\
\hline Montana & 83,368 & 19,630 & 7.2 \\
\hline North Dakota & 221,820 & 260,602 & 6.47 \\
\hline Texas & 65,761 & 49,511 & 7.09 \\
\hline
\end{tabular}

Once the states were selected, an investigation into relevant regulations and policies was conducted. This analysis primarily used state agency websites, as well as analysis of state and federal laws and policies, and legal texts as needed. As needed and when possible, experts at state and federal agencies were contacted.

\section{RESULTS}

Extracted waters are regulated at many points along the CCS life cycle. Depending on the state and the kind of project, regulation can occur when the water is withdrawn, that is, when it is accessed and removed from the saline aquifer. Regulation can occur when the water is re-injected in a close but unconnected aquifer. Regulation can also occur if the water is managed on the surface in an impoundment or with a dam. Finally, if the extracted water is treated or reused, regulations may also apply. This paper explores the first two avenues mentioned (extraction and reinjection) at both the federal and state levels, as appropriate.

\subsection{EXTRACTION}

The first area of regulation explored in this paper has to do with the withdrawal of extracted waters. This involves the drilling of a well to access the saline aquifer, any water right requirements to physically remove the water from the aquifer, and any pollution and anti-degradation requirements for accessing and using the groundwater.

It should be noted that the investigation in this section focuses on state laws and regulations. This is for two reasons: (1) for the most part, the active CCS projects in the United States are on private land, albeit with federal funding; and (2) for any future CCS projects that may be located on federal land, the federal government generally defers to states for management of groundwater resources. 


\subsubsection{State Regulations}

\subsubsection{California}

In California, withdrawal of surface waters and some kinds of groundwater are managed by the State Water Resources Control Board (SWRCB). There are three legal classifications of groundwater in the state: subterranean streams, underflow of surface waters, and percolating groundwater. Subterranean streams and underflow of surface waters are subject to the same laws as surface waters and are regulated by the SWRCB. Historically, in most areas of California, overlying landowners could pump percolating groundwater and put it to beneficial use without approval from the SWRCB, under the Doctrine of Correlative Rights. This doctrine limits the overlying users of groundwater to a reasonable share of the resource based on the amount of land they own.

However, in late 2014, the Governor of California signed into law three bills, AB 1739 and Senate Bills 1168 and 1319, which for the first time regulate the state's groundwater (CA.gov 2014). From the governor's announcement, "The bills establish a definition of sustainable groundwater management and require local agencies to adopt management plans for the state's most important groundwater basins" (CA.gov 2014). It is currently unclear what the implications of these new laws will be for water rights relating to extracted waters, or whether these laws could hinder growth of the CCS industry, mainly because the laws are not scheduled to take effect until between 2017 and 2022, depending on the groundwater basin.

The California Energy Commission, the California Public Utilities Commission, and the Air Resources Board formed a panel to review CCS policy and develop recommendations that could help guide legislation and regulations regarding CCS in California (CA.gov 2015a). In December 2010, the panel issued a report of its findings. The regulatory environment of CCS was discussed in depth and the panel concluded that, "There is no single lead agency for the permitting of CCS projects in California. The current permitting process involves a multitude of federal, state, regional, and local agencies, each with its unique authorities and regulatory requirements. Often, the agencies act independently of one another, and permitting timeframes are not always closely coordinated" (CCS Panel 2010).

The Panel's report also indicates that while the Division of Oil, Gas, and Geothermal Resources (DOGGR) has the authority to regulate EOR projects, it "does not currently have the authority to permit geologic sequestration projects where enhanced recovery is not taking place." Under the current law, the DOGGR regulates the drilling and operation of Class II wells under delegated authority from the EPA. The DOGGR also sets requirements for "any subsurface injection of fluids for enhanced recovery of oil or natural gas, or for fluids that are brought to the surface in connection with conventional oil or natural gas production." The Panel's report recommends that the DOGGR become 
the lead agency for "activities related to the subsurface" and that the SWRCB become the lead for water quality issues related to CCS activities.

Although bifurcating responsibility between DOGGR and SWRCB makes sense, as the DOGGR has experience with subsurface issues, and the SWRCB has extensive experience with water quality, adding complexity to the permitting and development process may impede adoption of CCS. This bifurcation combined with the requirement for local agencies to adopt groundwater management plans could lead to different and potentially convoluted permitting processes across the state, which may present another challenge to CCS activities.

\subsubsection{Illinois}

In Illinois, the Division of Oil and Gas in the Office of Mines and Minerals of the Illinois Department of Natural Resources (IDNR) regulates exploration and development of oil and gas. As with other states discussed in this section, it is unclear whether Illinois would consider extracted water activities, and also more broadly, CCS activities, to be oil and gas related, and therefore under their purview.

That being said, the Illinois Department of Agriculture is required to regulate water withdrawals through a registration process detailed in the Water Use Act of 1983 (525 Illinois Compiled Statutes [ILCS] 45). The Act was meant to establish a means of reviewing potential water conflicts before they occur. It also adopts the Reasonable Use Doctrine for groundwater in the state, which is a modification of the Rule of Capture discussed below in regard to Texas. This doctrine states that water must be put to a reasonable use on the overlying tract of land (Sax et al. 2006). In terms of water rights, there is no general permitting system in place for water withdrawals in Illinois for either surface water or groundwater.

It should be noted that although the Reasonable Use Doctrine applies to groundwater, the Correlative Rights Doctrine applies to oil and gas resources, as specified in the Illinois Oil and Gas Act (225 ILCS 725). As mentioned above for California's groundwater, this limits the owner of an oil and gas well to a reasonable amount of the resource based on the amount of overlying land the owner possesses. This distinction between legal doctrines for groundwater and oil and gas resources could have implications for how extracted waters are managed and regulated, depending on whether or not CCS is considered an oil and gas related activity.

As detailed in the Water Use Act, if a developer wants to drill an extracted water withdrawal well, and that well is considered "high-capacity" (i.e., it will produce more than 100,000 gallons per day), the developer must notify the applicable Soil and Water Conservation District (SWCD) before construction of the well begins (525 ILCS 45). 
The SWCD then notifies other local units of government with water systems that may be impacted by the proposed withdrawal. Along with the Illinois State Water Survey and the State Geological Survey, the SWCD then analyzes the withdrawal's effect upon other water users. The SWCD can place limits on the quantity withdrawn if a conflict will occur at the proposed pumping rate. In addition, the developer may have to file a Well Completion Report with the Illinois Environmental Protection Agency (IEPA 2002).

Finally, the Illinois Pollution Control Board has some anti-degradation measures that apply to certain categories of groundwater (Title 35, Part 620, Illinois Administrative Code [35 IAC 620]). According to 35 IAC 620, it appears extracted waters would be classified as "Class IV - Other Groundwater" by the state. This is defined as "Groundwater that naturally contains more than 10,000 mg/L of TDS" (35 IAC 620). However, no quality parameters are associated with Class IV groundwater under this law.

\subsubsection{Mississippi}

In Mississippi, the Department of Environmental Quality (DEQ) Office of Land and Water Resource's Division of Permitting and Monitoring (DPM) is responsible for issuing permits relating to the withdrawal of groundwater. It is also responsible for regulating and managing state water resources, and for maintaining the observation well network that monitors water levels associated with major aquifers in the state (MDEQ 2007). The Mississippi Oil and Gas Board (MSOGB) is responsible for oil and gas permitting within the state.

Freshwater is defined under the state's Administrative Code (MAC) as having less than $1,000 \mathrm{mg} / \mathrm{L}$ TDS (11 MAC 6), while groundwater is defined as simply "water beneath the ground." Given these definitions, it is likely that most extracted waters would not be considered fresh. Based on consultation with a technician in the DPM, it appears that an extracted water withdrawal well would fall under regulations detailed in 11 MAC 6. These regulations stipulate that an extracted water withdrawal well (or any groundwater well) would need a permit only if (1) the well casing is larger than 6 inches, or (2) the water will be going into a surface impoundment (11 MAC 7). Because the well casing for an extracted water withdrawal well is almost certain to be larger than 6 inches, these wells would need to seek permits from the DPM.

11 MAC 7 further classifies groundwater wells based on their intended use. Ten well types are detailed in the regulation. Although none specifically describe an extracted water well, it seems it would be classified as either a "dewatering well" or a "recovery well." A dewatering well is defined as "a well used for temporary removal of surface water or groundwater to facilitate construction or mining operations," while a recovery well is defined as "a well constructed for the purpose of recovering undesirable groundwater for treatment or removal of contaminants" (11 MAC 7). While the principle intent of a recovery or dewatering well (to manage and treat fluids on the 
surface) is different from that of an extracted water well (to manage subsurface pressure), the impact on the subsurface is much the same. And because new policies and regulations are often slow to form or come into force, it is important to understand what existing regulations may apply to CCS to aid the developers of CCS projects in their planning efforts.

In addition, although provisions are in place to govern the abandonment of wells once they are no longer in use, saline water wells associated with enhanced oil and gas recovery operation, brine withdrawal wells, and other types of onsite oil and gas well holes are specifically excluded from these provisions. It is not clear whether the state would consider CCS activities as oil and gas related, but this is likely to be the case, particularly given the similarity between extracted water withdrawal wells and the brine withdrawal wells.

Finally, in terms of water rights, although Mississippi lies east of the Mississippi River, it is actually considered to have a mix of legal doctrines governing water, and thus has elements of both riparianism and prior appropriation (Sax et al. 2006). As such, requirements are in place for obtaining a water permit prior to extracting groundwater. To this end, there is a beneficial use hierarchy described in 11 MAC 7 that is referred to when there is a conflict over water and/or groundwater use. In the hierarchy, industrial uses are second, behind public supply, but above livestock, commercial, and environmental uses (11 MAC 7). Although industrial use requests must include an examination of water quality and quantity needs, with an investigation into alternative supplies, such as poor quality aquifers, this is unlikely to be burdensome in the case of an extracted water withdrawal well, given that it is already using "poor" quality water. In addition, conflict over groundwater from saline aquifers is unlikely.

\subsubsection{Montana}

In Montana, groundwater is defined as "any water that is beneath the ground surface," in Montana Code Annotated (MCA) §85-2-102(11) (Montana DEQ 2014). Montana recognizes the doctrine of prior appropriation for groundwater. A person may not appropriate water or commence construction without a permit from the Montana Department of Natural Resources (MDNR) Water Resources Bureau. In the Water Bureau's New Appropriation Rules (Mont. Admin. Rul. 36.12.101.2001 [2005]), there are different criteria for obtaining a permit depending on how much water is required. If the amount is less than 4,000 acre-feet, the applicant must show, among other things, that the water is available, that other appropriators will not be adversely affected, and that the proposed use is beneficial. If the appropriation is for more than 4,000 acre-feet per year and 5.5 cubic feet per second (cfs), the applicant must also prove that the use is reasonable.

Harto and Veil (2011) reported that CCS facilities would need to use approximately 9 barrels of water (378 gallons) for every metric ton of $\mathrm{CO}_{2}$ sequestered. The Kemper 
Project in Mississippi, used here as an example of an active CCS project as one does not currently exist in Montana, will sequester 3.5 million metric tons per year when it is completed, which means one would need to extract approximately 1.3 billion gallons of water annually ( 1 acre-foot is equivalent to 325,851 gallons of water). This figure is very close to 4,000 acre-feet per year. This, of course, assumes $100 \%$ of emissions would be sequestered, which is unlikely.

In addition, although the state has a general beneficial use hierarchy for water management decisions, under MCA $\S 85-2-317$, groundwater also has an additional requirement: the MDNR may not approve a permit to appropriate groundwater in excess of 3,000 acre-feet per year unless the MDNR also petitions the legislature and the legislature affirms the MDNR's decision after one or more public hearings.

Finally, the Montana Board of Oil and Gas Conservation has jurisdiction over oil and gas wells in the state. An applicant would need a permit from the Board to drill a well if extracted waters are considered an oil and gas related activity. However, the MDNR Board of Water Well Contractors would permit the well if extracted water is not considered oil and gas related. Well requirements set by the Board are enumerated in the Administrative Rules of Montana (36 ARM 21).

\subsubsection{North Dakota}

In North Dakota, the North Dakota Century Code (NDCC) refers to statutory law and the North Dakota Administrative Code (NDAC) refers to regulations. Under Title 33, Section 18 of NDAC, a well is defined as, any opening "through which ground water flows under natural pressure or is artificially withdrawn; provided, that this definition does not include a natural spring, stock ponds, or holes drilled for the purpose of exploration for production of oil, gas, gravel, or other minerals" (NDAC 2016a). From this definition, as with other states, whether or not CCS activities are considered to be for the production of oil or gas is going to be crucial to whether or not extracted water wells are considered water wells.

The North Dakota Department of Health (NDDH) Groundwater Division regulates and permits the construction of groundwater wells in the state. Rules and regulations under Title 33, Section 18 of the NDAC are fairly straightforward, with an applicant needing to apply for approval of the Groundwater Division. Conditions for well approval include taking into consideration siting, construction standards, casing requirements, and other requirements. Per NDAC 33-18-01-03, subsection 5, North Dakota also requires issuance of a conditional water permit as "waters of the state" of North Dakota belong to the public and are subject to appropriation for beneficial use pursuant to the NDCC Chapter 61-04 (NDCC 2016a). Waters of the state, defined in NDCC 61-01, include "waters under the surface of the earth whether such waters flow in defined subterranean channels or are diffused percolating underground water," (NDCC 2016b). It should be noted that NDAC 33-18 specifies that "All wells designed as water supply wells, geothermal groundwater, or return wells, or special purpose water wells shall be constructed in accordance with this 
chapter" (NDAC 2016a). If CCS extracted water wells are classified and managed as water wells, they would almost certainly fall under the "special purpose water well" description above.

Oil and gas wells are managed by the North Dakota Industrial Commission, Department of Mineral Resources, Oil and Gas Division under Title 43, Section 02 (NDAC 2016b). Provisions here are also common and straightforward. Section 43-02-03-47 details management of produced water, which, while not identical to extracted water, could be managed in a similar fashion. Section 43-02-03-53 deals with management of saltwater and brines produced during oil and gas development, which also could be applicable to extracted water management.

\subsubsection{Texas}

Drilling an extracted water well in Texas, as in other states, depends on whether or not the state considers CCS activities to be oil and gas related activities. Under the Texas Natural Resources Code, Title 3, and the Texas Water Code, Chapters 26 and 27, the Railroad Commission (RRC) has jurisdiction over all activities associated with "the exploration, development, or production of oil or gas or geothermal resources" (RRC 2014). The Texas Water Code (TWC) indicates that the RRC does have jurisdiction over the "geologic storage of carbon dioxide into a reservoir that is initially or may be productive of oil, gas, or geothermal resources or a saline formation directly above or below that reservoir," and all wells related to this purpose (2 TWC 27). However, extracted water production is not explicitly listed among the provisions in this law. When contacted, RRC intimated that although this is not expressly specified, water extraction would likely fall under its jurisdiction because of authority granted in TWC Section 27.041(a), as well as that of the relevant local groundwater conservation district, which may require an additional permit (Texas RRC, Personal Communication, January 28, 2015).

If the state considers extracted water production for CCS projects to fall under its jurisdiction, then the RRC requires a permit for wells associated with oil and gas activities, even those that withdraw brackish or highly saline water from formations below the Underground Source of Drinking Water (USDW) zone (RRC 2014). These regulations are detailed in RRC Statewide Rule 5 (16 TAC §3.5), which requires an RRC drilling permit to "drill an injection water supply well that penetrates the base of usable quality water" (RRC 2014). In addition, Statewide Rule 13 (16 TAC §3.13) requires that the well be completed in accordance with the criteria in the rule. Finally, the injection supply water well must be plugged in accordance with Statewide Rule 14 (16 TAC $\$ 3.14)$.

Finally, the extracted water project must also have the legal right to withdraw the groundwater. Groundwater management in Texas is organized around the Rule of 
Capture, with overlying landowners granted the ability to use as much water as they need, without liability to surrounding landowners. There may be some stipulations if the land lies within a Groundwater Conservation District (GCD). However, provisions relating to management of GCDs generally do not apply to production or injection wells drilled for oil or gas, or for the injection of oil and gas related fluids under permits issued by the RRC (RRC 2014). However, they do apply to water wells, including injection water source wells "used to supply water for activities related to the exploration or production of hydrocarbons or minerals" (§36.117(1)). Extracted water source wells would seem to fall into this latter category, if indeed the RRC has jurisdiction over extracted water.

Applicable state-level extracted water regulatory authorities and water law regimes described in this section are summarized in Table 2. 
TABLE 2 - Summary of State-Level Extracted Water Regulatory Authorities and Applicable Water Law Regimes

\begin{tabular}{|c|c|c|c|c|c|c|}
\hline & California & Illinois & Mississippi & Montana & North Dakota & Texas \\
\hline $\begin{array}{c}\text { Groundwater } \\
\text { Regulating } \\
\text { Authority }\end{array}$ & $\begin{array}{c}\text { California } \\
\text { State Water } \\
\text { Resources } \\
\text { Control } \\
\text { Board }\end{array}$ & $\begin{array}{l}\text { Illinois } \\
\text { Department of } \\
\text { Agriculture } \\
\text { (quantity); } \\
\text { Illinois } \\
\text { Pollution } \\
\text { Control Board } \\
\text { (quality) }\end{array}$ & $\begin{array}{c}\text { Mississippi } \\
\text { Department of } \\
\text { Environmental } \\
\text { Quality Office } \\
\text { of Land and } \\
\text { Water } \\
\text { Resources } \\
\text { Division of } \\
\text { Permitting and } \\
\text { Monitoring } \\
\end{array}$ & $\begin{array}{c}\text { Montana } \\
\text { Department } \\
\text { of Natural } \\
\text { Resources } \\
\text { Water } \\
\text { Resources } \\
\text { Bureau }\end{array}$ & $\begin{array}{l}\text { North Dakota } \\
\text { Department of } \\
\text { Health, } \\
\text { Groundwater } \\
\text { Division }\end{array}$ & $\begin{array}{c}\text { Texas } \\
\text { Commission } \\
\text { on } \\
\text { Environmental } \\
\text { Quality }\end{array}$ \\
\hline $\begin{array}{c}\text { Oil \& Gas } \\
\text { Regulating } \\
\text { Authority }\end{array}$ & $\begin{array}{l}\text { California } \\
\text { Division of } \\
\text { Oil, Gas, and } \\
\text { Geothermal } \\
\text { Resources }\end{array}$ & $\begin{array}{c}\text { Illinois } \\
\text { Department of } \\
\text { Natural } \\
\text { Resources } \\
\text { Office of } \\
\text { Mines and } \\
\text { Minerals } \\
\text { Division of } \\
\text { Oil and Gas }\end{array}$ & $\begin{array}{l}\text { Mississippi } \\
\text { Oil and Gas } \\
\text { Board }\end{array}$ & $\begin{array}{c}\text { Montana } \\
\text { Board of Oil } \\
\text { and Gas } \\
\text { Conservation }\end{array}$ & $\begin{array}{c}\text { North Dakota } \\
\text { Industrial } \\
\text { Commission, } \\
\text { Department of } \\
\text { Mineral } \\
\text { Resources, Oil } \\
\text { and Gas Division }\end{array}$ & $\begin{array}{c}\text { Railroad } \\
\text { Commission of } \\
\text { Texas }\end{array}$ \\
\hline $\begin{array}{l}\text { Groundwater } \\
\text { Law Regime }\end{array}$ & $\begin{array}{c}\text { Prior } \\
\text { Appropriation }\end{array}$ & $\begin{array}{c}\text { Reasonable } \\
\text { Use Riparian } \\
\text { (groundwater); } \\
\text { Correlative } \\
\text { Rights } \\
\text { (oil \& gas) }\end{array}$ & $\begin{array}{c}\text { Mix of } \\
\text { Riparianism } \\
\text { and Prior } \\
\text { Appropriation }\end{array}$ & $\begin{array}{c}\text { Prior } \\
\text { Appropriation } \\
\text { w/ Beneficial } \\
\text { Use Hierarchy }\end{array}$ & $\begin{array}{c}\text { Prior } \\
\text { Appropriation } \\
\text { w/ Beneficial } \\
\text { Use Hierarchy }\end{array}$ & $\begin{array}{l}\text { Rule of } \\
\text { Capture }\end{array}$ \\
\hline
\end{tabular}

\subsection{INJECTION}

One of the simplest methods of disposal for extracted waters may be reinjection at a site close to but not within a geologically connected area or injection zone. Analyzing the injection permitting environment at the federal and state levels is an important starting point for understanding the complex, and often confusing, regulatory environment in which extracted water management occurs.

\subsubsection{Federal Regulations}

Injection wells are regulated by the EPA under the authority of the Underground Injection Control (UIC) program, as provided by Part C of the Safe Water Drinking Act (Title 40, Code of Federal Regulations, Parts 144-147 [CFR Parts 144-147]). The UIC Program divides water injection into six classes, based on "similarity in the fluids injected, activities, construction, injection depth, design, and operating techniques" (EPA 2012a). Currently, there are six categories (Class I through Class VI). Class VI is the most recently created category, specifically designed for underground injection of 
$\mathrm{CO} 2$ for CCS projects. At first glance, Class VI might seem to be the logical choice for extracted waters because of the similarity of use; however, this would be incorrect.

After lengthy correspondence with an EPA Office of Ground Water and Drinking Water geologist, who is also a member of the National UIC Technical Working Group, it was determined that the important factor for determining classification of extracted water for injection is whether or not the water is "drinkable," that is, whether or not it can be considered an USDW as defined under 40 CFR 144.3. These sources, by definition, have TDS levels of $10,000 \mathrm{mg} / \mathrm{L}$ or less. If extracted water falls within this TDS range, it can be injected into a Class V well. This is by far the largest category of UIC wells, including most wells in the United States (between 400,000 and 650,000 in 2012 by the EPA's own estimates). This category "injects non-hazardous fluids into or above USDW [zones] and are typically shallow, on-site disposal systems" (EPA 2012a).

However, according to Harto and Veil (2011), median TDS values of extracted waters range from $5,000 \mathrm{mg} / \mathrm{L}$ to more than $300,000 \mathrm{mg} / \mathrm{L}$. Although $59 \%$ of formations had values less than $40,000 \mathrm{mg} / \mathrm{L}$, approximately $15 \%$ of formations had values greater than $160,000 \mathrm{mg} / \mathrm{L}$. It is therefore very likely that extracted waters would not be considered USDW, and would instead fall into a different UIC class. This would likely be Class I. Class I is one of the smaller classes, including approximately 680 wells nationwide and designated for injection of "hazardous wastes, industrial non-hazardous liquids, or municipal wastewater beneath the lowermost USDW" (EPA 2012a). These wells inject material deep into isolated rock formations that are many thousands of feet below the lowermost USDW zone. There are four types of Class I wells, and extracted waters would likely fall into the second type, nonhazardous industrial waste disposal wells (EPA 2012b). This type represents approximately $48 \%$ of all Class I wells.

Every Class I well must obtain a permit from the UIC Program that is valid for up to 10 years. Owners and operators of Class I wells must meet specific requirements to obtain this permit, including stipulations related to activities such as siting, construction, operation, monitoring, testing, and closure. This contrasts with Class V wells, which are more loosely regulated and therefore, easier to obtain a permit for.

Finally, if the EPA decides that extracted waters and CCS activities more broadly fall into the oil and gas category, it is possible extracted waters could be managed through UIC Class II wells. Class II wells inject fluids associated with oil and natural gas production.

Most of the injected fluid is brine, similar to extracted waters, that is brought to the surface in the process of producing oil and gas (EPA 2012c). These brines are disposed of in Class II disposal wells. In addition, brine and other fluids can also be injected to enhance oil and gas production via enhanced oil recovery Class II wells. It is important to note that, in the past, some states have allowed the injection of saline brines that are 
not oil and gas related to be injected into Class II wells, so there exists some precedence for this kind of use (Clark and Veil 2009).

It is important to note that the term "likely" is used above because there is currently no legislation on extracted water management to which the authors could refer. This classification is based on the current regulatory environment and consultation with experts in the field. The EPA could, in the future, choose to regulate these projects on a case- by-case basis, or issue some form of broader rulemaking detailing all extracted water wells fall under a certain category.

\subsubsection{State Regulations}

When discussing state regulations, it is also important to understand how the federal and state governments interact with regard to the injection of water. While the federal government is responsible for regulating the injection of water, in certain cases, it can relinquish responsibility to the state if it believes the state will do a sufficient job. This is called primacy.

Primacy programs are established under two sections of the Safe Drinking Water Act (SDWA). Section 1422 of the SDWA requires that primacy applicants meet the EPA's minimum requirements for UIC programs. Programs authorized under Section 1422, referred to as 1422 programs, have primacy for Class I, II, III, IV, V, and VI wells (EPA 2016). Section 1425, which applies only to Class II wells, requires primacy applicants to demonstrate that their standards are effective in preventing endangerment of drinking water sources. In addition, they are not required to meet the EPA's minimum requirements as long as they can show that their standards protect USDWs. The EPA may grant primacy for all or part of the UIC Program, which means that in some jurisdictions, primary enforcement authority for certain well classes may be shared with the EPA (EPA 2016)

\subsubsection{California}

California has partial delegated authority from the EPA for Class II wells (which are regulated by the DOGGR) and Class $\mathrm{V}$ geothermal wells (also regulated by the DOGGR). The other classes of UIC wells are regulated by EPA Region 9 under 40 CFR Part 144. These regulations are detailed in Section 3.2.1.

In California, operators of Class II injection wells must first file for a permit with the DOGGR (CA.gov 2015b). Before a permit is issued, the proposed injection project is studied and reviewed by the appropriate Regional Water Quality Control Board (RWQCB) using geologic and engineering data and public input. Injection project permits include many conditions, such as approved injection zones, allowable injection pressures, and testing requirements (CA.gov 2015b). 
It should also be noted that if CCS projects, and therefore extracted waters, are considered to be oil and gas related, and therefore, subject to regulation under DOGGR, they could possibly also be covered as deep Class V geothermal wells (which deal with brines that inject below the USDW). However, because of uncertainty in this area, it is not clear who will have jurisdiction for these activities in the future.

\subsubsection{Illinois}

In Illinois, the Illinois Environmental Protection Agency (IEPA) has jurisdiction over the administration of the UIC Program, which is detailed in Illinois Administrative Code, Title 35, Sections 704.101-704.289 (IAC 704.101-704.289) and 35 IAC 730.101730.195. This applies to all UIC classes except Class II, which falls under the jurisdiction of the Illinois Department of Natural Resources Office of Oil and Gas Resource Management (IDNR 2015).

Under the Illinois Administrative Code, a Class I well is defined as "1) A well used by a generator of hazardous waste or the owner or operator of a hazardous waste management facility to inject hazardous waste beneath the lowermost formation containing a USDW within 402 meters (one-quarter mile) of the well bore; 2) Any other industrial and municipal disposal well that injects fluids beneath the lowermost formation containing a USDW within 402 meters (one-quarter mile) of the well bore; and 3) A radioactive waste disposal well that injects fluids below the lowermost formation containing a USDW within 402 meters (one-quarter mile) of the well bore" (35 IAC 704). Extracted water injection wells would likely fall under the second of these definitions.

According to 35 CFR 704.161, unless an underground injection well is authorized by rule, all injection activities - including construction of an injection well-are prohibited until the owner or operator is authorized by permit. The application for a permit must be submitted to the IEPA in a "reasonable" amount of time before construction is expected to begin. For a Class I hazardous injection well, the permit must include, among other things, detailed specifications of the waste to be injected, as well as the names and contact information of all people within a quarter of a mile of the wellbore. These regulations are set up with the assumption that a hazardous waste facility is performing the injection, which is not the case for extracted water. Therefore, these regulations would likely need to be better tailored for CCS activities like water extraction.

Interestingly, non-experimental Class $\mathrm{V}$ geologic sequestration wells are prohibited in Illinois, as detailed under 35 CFR 704.125. In addition, under 35 CFR 704.123d, the owner or operator of an existing Class II EOR well can request that the IEPA issue an USDW aquifer protection exemption for geologic carbon sequestration activities under Class VI wells. Finally, it should be noted that without specific extracted water provisions, it is entirely possible that in the future, the Office of Oil and Gas Resource 
Management may have jurisdiction over extracted water injection wells, rather than the IEPA.

\subsubsection{Mississippi}

The UIC Program in the State of Mississippi is administered by the Mississippi Oil \& Gas Board, which regulates Class II wells, and the Management Support Branch Department of Environmental Quality, which regulates all other well classes. These UIC regulations are detailed in the Mississippi Administrative Code (11 MAC 6).

Under 11 MAC 6, Class I wells are defined as "(1) Wells used by generators of hazardous waste or owners or operators of hazardous waste management facilities to inject hazardous waste beneath the lowermost formation containing, within five (5) miles of the wellbore, an underground source of drinking water; and (2) Other municipal and industrial disposal wells (including radioactive waste disposal wells) which inject fluids beneath the lowermost formation containing, within five (5) miles of the well bore, an underground source of drinking water" (11 MAC 6).

A person desiring a permit for a new Class I well must show that their waste can "reasonably and adequately" be disposed of in no other manner. It should be noted that, in the case of extracted waters, other disposal methods, such as treatment and reinjection into a Class II or Class V well, or surface disposal, are generally available (11 MAC 6). To consider whether underground injection is necessary, the DEQ can use factors such as cost, treatment reliability, effluent quality, indirect environmental impacts, and any others the Permit Board deems important (11 MAC 6). Finally, the person who wants the permit has to submit a report detailing the nature of the waste to be injected, treatability studies detailing alternate methods of treatment and disposal, and a detailed study explaining why each alternative analyzed is unsatisfactory.

\subsubsection{Montana}

With the exception of Class II wells, which are administered by the Montana Board of Oil and Gas Conservation, all other UIC wells in Montana are regulated by the EPA Region 8 Ground Water Program under 40 CFR Part 144. These regulations are detailed in Section 3.2.1 (EPA 2015b). Montana's Class II wells are regulated under the Administrative Rules of Montana, in 36 ARM 22.

It should be noted that, similar to California, if CCS projects - and therefore extracted waters - are considered oil and gas related, it is possible that they would be under the jurisdiction of the Board of Oil and Gas Conservation. However, it is currently uncertain who will have jurisdiction for these activities in the future. 


\subsubsection{North Dakota}

The North Dakota Department of Mineral Resources (NDDMR) Rule Book has a specific section on "Carbon Dioxide Underground Storage" (NDDMR 2016). This section, Title 38, Section 22, in the North Dakota Century Code, states that it is in the public interest to promote the geologic storage of $\mathrm{CO}_{2}$ and that doing so will "help ensure the viability of the state's coal and power industries, to the economic benefit of North Dakota and its citizens." This statement falls in line with the state's view that CCS development is an oil and gas endeavor, not a water-related one. Rules for the geologic storage of $\mathrm{CO}_{2}$ are described in NDAC 43-05-01.

Geologic storage of $\mathrm{CO}_{2}$ first requires a permit from the North Dakota Industrial Commission. The permit application process requires a fee and a public hearing, with notice given to every subsurface mineral rights owner within one-half mile of the reservoir, as well as all impacted surface landowners (NDDMR Rule Book §38-22-06). Before issuing a permit, the Commission must also consult with the state Department of Health. Once the permit is granted, a fee is then paid for each ton of $\mathrm{CO}_{2}$ injected underground.

However, because no mention is made of regulation or management for injecting extracted waters in the rules discussed above, it is prudent to look to general UIC regulations in the state. North Dakota has primacy from the EPA to administer Class I through Class V wells. In 2013, the state also applied for primacy for Class VI wells, and is the first state in the country to do so (ND.gov 2016). The EPA has yet to decide on that application.

UIC overview and administration are coordinated through the North Dakota Department of Health (NDDH) Division of Water Quality, under North Dakota Administrative Code, Title 33, Section 25 (NDAC 2016b). These regulations detail the UIC well classification system, how to apply for permits, requirements for public hearings, and other relevant information. However, nothing in Section 25 details how to classify or manage extracted waters. They could fall under Class II wells, which are defined as, "Wells which inject fluids which are brought to the surface in connection with conventional oil or natural gas production." This classification might make sense given the state's assertions in Title 38, Section 22 that CCS activities help ensure the viability of the state's coal and power industries. However, extracted waters could also be classified under Class I wells for hazardous waters, given the extremely high TDS values associated with these waters (they are the highest values of the states investigated in this paper by a large margin). Finally, oil and gas related UIC rules and regulations are also detailed in NDAC 43-02-05 (NDDMR 2016).

As in other states discussed in this paper, it is unclear who would manage the injection of extracted waters in North Dakota. However, given that Title 38, Section 22, details that 
oversight of CCS injection is delegated to the NDDMR, it is likely that these activities will be managed as oil and gas related, more so than water.

\subsubsection{Texas}

The Texas Commission on Environmental Quality (TCEQ) administers the UIC Program in the State of Texas. Rules regarding well casing and surface completion of injection wells are detailed under 30 TAC Part 1, Chapter 331, Subchapter H, Section 33.132.

Although there is no specific permit for the injection of extracted water, the Class I UIC General Permit WDWG010000 provides authorization for use of a Class I injection well to inject nonhazardous brine from a desalination operation or nonhazardous drinking water treatment residuals, which may be similar in nature to extracted water (TCEQ 2015). The permit process for the General Permit is fairly straightforward and involves submitting a Notice of Intent (NOI), after which point TCEQ staff will check it for completeness, make sure there is sufficient insurance, and check the submitter's compliance history if they already operate an existing facility. A Completion Report must also be submitted 90 days after the well is drilled (TCEQ 2015).

In addition, under Texas Water Code, Title 2, Subtitle D, Subchapter C-1, the injection of fluid through a Class II UIC well for EOR-related activities is not considered to fall under the law, which gives jurisdiction to the Texas RRC (2 TWC 27). This sets a precedent in which the RRC, rather than TCEQ, may have jurisdiction over injection of extracted waters in the future.

\section{CONCLUSION}

Extracted water exists in a murky legal environment. As part of a broader attempt to identify the complex interactions between water resource policies and CCS, an analysis was undertaken, at both the state and the federal level, to scope the policy environments surrounding extracted water management. In the six states investigated, it was found that no regulations exist for this source specifically. Greater input is also needed from regulators and policymakers in terms of defining this resource. In particular, extracted waters (and CCS activities broadly) often overlap with management of produced fluids during oil and gas development. Many regulations would apply to extracted waters if they were classified as such. Therefore, correct categorization is key as the industry in this space continues to grow.

\section{ACKNOWLEDGEMNTS}

The authors would like to thank the U.S. Department of Energy's (DOE's) National Energy Technology Laboratory (NETL) Carbon Sequestration Program for providing funding to support the project. The work was supported through Field Work Proposal 49607. 


\section{REFERENCES}

36 ARM (Administrative Rules of Montana) 21, "Board of Water Well Contractors." Available at http://www.mtrules.org/gateway/ChapterHome.asp?Chapter=36.21.

225 ILCS (Illinois Compiled Statutes) 725, "Illinois Oil and Gas Act.” Available at http://www.ilga.gov/legislation/ilcs/ilcs3.asp?ActID=1391\&ChapAct=225\%EF\%BF\%B DILCS\%EF\%BF\%BD725.

525 ILCS 45, "Water Use Act of 1983." Available at http://www.ilga.gov/legislation/ilcs/ilcs3.asp?ActID=1743\&ChapAct=525\%C2\%A0IL CS\%C2\%A045/\&ChapterID $=44 \&$ ChapterName $=$ CONSERVATION\&ActName $=$ Wate

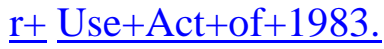

35 IAC (Illinois Administrative Code) 620, “Groundwater Quality.” Available at http://www.ipcb.state.il.us/documents/dsweb/Get/Document-33425.

35 IAC 704, “UIC Permit Program.” Available at http://il.eregulations.us/rule/t35_pt704.

11 MAC (Mississippi Administrative Code) 6, "Wastewater Pollution Control Regulations." Available at http://www.deq.state.ms.us/mdeq.nsf/pdf/legal_11Miss.Admin.CodePt.6Ch.1./\$File/11\% 20Miss.\%20Admin.\%20Code\%20Pt.\%206\%20Ch.\%201..pdf?OpenElement.

11 MAC 7, "Surface Water and Groundwater Use and Protection, Licensing of Water Well Contractors and Dam Safety Regulations." Available at http://www.deq.state.ms.us/mdeq.nsf/pdf/legal_11Miss.Admin.CodePt.7,Ch.1/\$File/11\% 20Miss.\%20Admin.\%20Code\%20Pt.\%207,\%20Ch.\%201..pdf?OpenElement.

2 TWC (Texas Water Code) 27, "Injection Wells.” Available at http://www.statutes.legis.state.tx.us/Docs/WA/htm/WA.27.htm.

CA.gov, 2014. Governor Brown Signs Historic Groundwater Legislation. September 16. Available at http://gov.ca.gov/news.php?id=18701.

CA.gov, 2015a. California Carbon Capture and Storage. Available at http://www.climatechange.ca.gov/carbon_capture_review_panel.

CA.gov, 2015b, Oil, Gas \& Geothermal - Injection Wells. Available at http://www.conservation.ca.gov/dog/general_information/Pages/class_injection_wells.as $\underline{\mathrm{Px}}$. 
CCS (Carbon Capture and Storage Review) Panel, 2010. Findings and Recommendations by the California Carbon Capture and Storage Review Panel. December. Available at http://www.climatechange.ca.gov/carbon_capture_review_panel/documents/2011-0114_CSS_Panel_Recommendations.pdf.

Clark, C.E. and Veil, J.A., 2009, Produced Water Volumes and Management Practices in the United States, ANL/EVS/R-09/1, Argonne National Laboratory, Argonne, IL. Available at http://www.ipd.anl.gov/anlpubs/2009/07/64622.pdf.

EPA (U.S. Environmental Protection Agency, 2012a. Classes of Wells. August 2. Available at http://water.epa.gov/type/groundwater/uic/wells.cfm.

EPA, 2012b. Industrial \& Municipal Waste Disposal Wells (Class I). March 6. Available at http://water.epa.gov/type/groundwater/uic/wells_class1.cfm.

EPA, 2012c. Oil and Gas Related Injection Wells (Class II). May 9. Available at http://water.epa.gov/type/groundwater/uic/class2/

EPA, 2015a. Underground Injection Control (UIC). September 30. Available at http://www3.epa.gov/region09/water/groundwater/uic.html.

EPA, 2015b. Underground Injection Control. June 24. Available at http://www2.epa.gov/region8/underground-injection-control.

EPA, 2016. Primary Enforcement Authority for Underground Injection Control Program, Feb. 12. Available at https://www.epa.gov/uic/primary-enforcement-authorityunderground-injection-control-program.

Harto, C.B., Veil, J.A., 2011. Management of Water Extracted from Carbon Sequestration Projects, ANL/EVS/R-11/1, Argonne National Laboratory, Argonne, IL. Available at http://www.ipd.anl.gov/anlpubs/2011/03/69386.pdf.

IDNR (Illinois Department of Natural Resources), 2015. Oil \& Gas Resource Management. Available at http://www.dnr.illinois.gov/OilandGas/Pages/default.aspx.

IEPA (Illinois Environmental Protection Agency), 2002. Well Completion Report. February 6. Available at http://www.epa.state.il.us/land/regulatory-programs/permitsand-management/forms/well-completion.pdf.

Kobos, P.H., J.L. Krumhansl, T.A. Dewers, J.E. Heath, M.A. Cappelle, D.J. Borns, G.T. Klise, B.P. Dwyer, and A. McNemar, 2009. "Combining Power Plant Water Needs and Carbon Storage Using Saline Formations: An Assessment Tool," presented at the Eighth Annual Conference on Carbon Sequestration and Storage, Pittsburgh, PA, May 4-7. 
MDEQ (Mississippi Department of Environmental Quality), 2007. Permitting and Monitoring. Available at

http://www.deq.state.ms.us/MDEQ.nsf/page/L\&W_Permitting_and_Monitoring?OpenDo cument.

Montana DEQ (Montana Department of Environmental Quality), 2014. Montana Water Quality Statutes \& Administrative Rules. Available at http://deq.mt.gov/wqinfo/laws_rules.mcpx.

ND.gov. 2016. Class VI Primacy Application for the authority to regulate the Geologic Storage of Carbon Dioxide. Available at https://www.dmr.nd.gov/oilgas/GeoStorageofCO2.asp.

NDAC (North Dakota Administrative Code), 2016a. “Article 33-18, Water Well Contractors." Available at http://www.legis.nd.gov/information/acdata/pdf/33-1801.pdf.

NDAC, 2016b. "Article 33-25, Underground Injection Control.” Available at http://www.legis.nd.gov/information/acdata/pdf/33-25-01.pdf .

NDCC (North Dakota Century Code), 2016a. "Chapter 61-04, Appropriate of Water." Available at http://www.legis.nd.gov/cencode/t61c04.pdf .

NDCC, 2016b. “Chapter 61-01, General Provisions.” Available at http://www.legis.nd.gov/cencode/t61c01.pdf .

NDDMR (North Dakota Department of Mineral Resources), 2016. Rule Book. Available at https://www.dmr.nd.gov/oilgas/rules/rulebook.pdf.

RRC (Railroad Commission of Texas), 2014. Eagle Ford-Water Use. Available at http://www.rrc.state.tx.us/oil-gas/major-oil-gas-formations/eagle-ford-shale/wateruse.

Sax, J.L., Thompson, B., Leshy, J., Abrams, R., 2006. Legal Control of Water Resources (4th ed.). Thomson/West, St. Paul.

TCEQ (Texas Commission on Environmental Quality), 2015. Class I Injection Wells Regulated by the TCEQ. July 20. Available at http://www.tceq.state.tx.us/permitting/waste_permits/uic_permits/UIC_Guidance_Class 1.html/\#Guidance. 